\title{
Comment
}

\section{Public communication from research institutes: is it science communication or public relations?}

\section{Rebecca B. Carver}

\begin{abstract}
There is growing competition among publicly funded scientific institutes and universities to attract staff, students, funding and research partners. As a result, there has been increased emphasis on science communication activities in research institutes over the past decade. But are institutes communicating science simply for the sake of improving the institute's image? In this set of commentaries we explore the relationship between science communication and public relations $(P R)$ activities, in an attempt to clarify what research institutes are actually doing. The overall opinion of the authors is that science communication activities are almost always a form of PR. The press release is still the most popular science communication and PR tool. There is however disagreement over the usefulness of the press release and whether or not gaining public attention is actually good for science.
\end{abstract}

Science communication may be defined as the use of appropriate skills, media, activities and dialogue to communicate about scientific research to the public, in order to produce one or more of the following: awareness, enjoyment, interest, opinions and/or understanding about science [1]. Common science communication activities practiced in communication and PR departments in research institutes include issuing press/news releases, writing news and feature articles on their website, posting videos, blogs, presentations or podcasts and producing museum exhibits or open days.

Public relations (PR) can be defined as "the distinctive management function which helps establish and maintain mutual lines of communication, acceptance and cooperation between the organization and its publics" [2] PR is usually aimed at making an institution look good and helping it achieve its strategic goals, such as elevated prestige among its peers or increased research funding. The most important tool for PR work is the press release. Indeed, it is also the most commonly used tool in institutional science communication. It is therefore through the press release that both PR and science communication inevitably become entwined. 


\section{The worth of the press release}

The press release is essentially a short news article written in a journalistic style that explains a newly published scientific result in a common and not too specialized language. The press release puts the results into context and shows the reader the relevance and perspectives of the new findings. It also increases the likelihood of the media reporting on the research, which in turn can increase visibility and attract public interest in both the research and the institute. This, it seems, has become the ultimate goal of research institutes.

Charlotte Autzen makes a clear and important distinction between the role of the press officer who issues press releases from a research institute, and the role of the critical science journalist who acts like a "watch dog". Research institutes frame their stories in a way that suits their goals - for example, for getting attention, not just from the public, but also the stakeholders such as politicians and funders. Autzen argues that whilst the press release is an example of genuine science communication, we still need science journalists out there who can put the research into context, and also ask critical questions about the motives of the research institute where the work was conducted - for example, questions about the institutes' priorities, financing, and their self-claimed privileged position as knowledge producers. She argues that they should start showing an interest, not in how the institutions write the individual science story or press release, but how they frame science in a much broader sense.

Whilst Autzen argues for the worth of the press release, in contrast, Michel Claessens believes research institutes are doing neither science communication nor public relations, because communicating via a press release is not genuine communication. Real communication involves dialogue, and Claessens believes this is almost absent from institutional communication. In addition, most research institutions target in priority their 'stakeholders', which include decision-makers, politicians and the scientific community, rather than the general public. True public dialogue is therefore lacking.

In line with Claessens, Frank Marcinkowski and Matthias Kohring argue that the institutionalized "push" communication, for example in the form of press releases, has become the dominant form of public science communication and has tended to force other forms and functions of science communication into the background. They believe this form of science communication focuses too much on gaining public attention, and is not necessary for the functioning of science - it can actually represent a potential threat to the autonomy of scientific research. This is because the battle for public attention drives institutes to self-promotion, image building and image maintenance and self-marketing — basically, all non-scientific motives.

\section{Is public visibility a good thing?}

Universities seem to believe that there simply cannot be enough media publicity and public attention. The so-called "mediatization" of academic institutions is, as Marcinkowski and Kohring put it, a "PR strategy to enable universities to survive and thrive in an artifi- 
cial competition for financial resources..." They call it "artificial" because they believe the exaggerated pursuit of public attention is entirely detached from the internal logic of science itself. This can, for example, lead research groups into choosing their topics purely on the basis of the topic's potential for attention and popularity.

On the contrary, Matt Shipman argues that increased media coverage can be a good thing for science because it can aid the discovery of scientific findings within the research community. Shipman describes a classic study by Phillips et al. [3], which showed that newspaper coverage of research findings made it more likely that the journal article would be cited [3]. This is especially true for multidisciplinary work that normally has difficulty being visible to all its relevant sub-fields.

In line with Matt Shipman, Charlotte Autzen provides data showing that the most highly ranked universities are those that issue the most press releases and have the most public attention in the news media. Although university ranking systems can be questioned, it seems as though increased media coverage is associated with academic prestige.

But what about the effect on the public? Whilst the general view here is that PR activities are, deep down, mostly targeting stakeholders rather than the public, Matt Shipman reminds us that other communication tools like blog posts and online feature articles can help attract the interest of promising new researchers and graduate students - which is also an important goal for the public communication efforts of research institutes.

\section{What should research institutes be doing?}

There is evidently still a lot to be said and done about the type of communication that is being practiced from publicly funded research institutes. In this commentary section, Michel Claessens argues that the priority of research institutes should be the development of a genuine science communication context that involves dialogue with the public. For example, it could be through the training of scientists for public engagement activities, or the organization of public consensus conferences. Frank Marcinkowski and Matthias Kohring would also like to see more involvement with the lay public and less focus on the media, and Charlotte Autzen would like to see science journalists being more critical to the motives of the science institutions. Ending on a positive note, Matt Shipman believes that as long as research findings are not exaggerated, PR can "help bolster support for research funding. It can help inspire the next generation of researchers. And it can help to remind the public of what scientists are working on and why."

\section{References}

[1] T.W. Burns, D.J. O’Connor and S.M. Stocklmayer (2003), "Science Communication: A Contemporary Definition”, Pub. Underst. Sci. 12: 183-202.

[2] R. Harlow (1984), Managing Public Relations, Holt, Rinehart and Winston, New York, U.S.A. .

[3] D.P. Phillips et al. (1991), "Importance of the lay press in the transmission of medical knowledge to the scientific community", New Engl. J. Med. 325: 1180-1183. 


\section{Author}

Rebecca B. Carver is a communications advisor at the Norwegian Institute of Public Health, and is currently on a year's leave to conduct research into the public understanding of genomics at the Federal University of Bahia, Brazil. She holds a PhD in science communication, and has conducted research into the media's framing of the gene concept. E-mail: rebecca.carver@gmail.com.

How TO CITE: R.B. Carver, "Public communication from research institutes: is it science communication or public relations?", JCOM 13(03)(2014)C01. 